Vera Stojčevska-Antik'

Uniwersytet św. Cyryla i Metodego

w Skopju

vera39antic@gmail.com
Data przesłania tekstu do redakcji: 24.04.2014

Data przyjęcia tekstu do druku: 22.05.2014

\title{
Tradycja chrześcijańska na Bitolszczyźnie i we wsi Nowaci
}

Aвstract: Stojčevska-Antik' Vera, Tradycja chrześcijańska na Bitolszczyźnie $i$ we wsi Nowaci (Christian Tradition on Bitolszczyzna and in the Village Nowaci). „Poznańskie Studia Slawistyczne" 10. Poznan 2016. Publishing House of the Poznań Society for the Advancement of the Arts and Sciences, pp. 379-386. ISSN 2084-3011.

The paper portrays the Macedonian folk Christianity, existing outside the official Church. Systematic scientific researches, also conducted nowadays, have shown that this phenomenon is not only still alive, but it is even growing - especially after 1989, when the Church in Macedonia started to recover. In the mainstream of popular Christianity, the Marian tradition is represented most strongly. Macedonians believe that the Mother of God since time immemorial until today has been personally involved in the construction of their church - as well in the spiritual as in the material meaning. An example could be the village Nowaci from Bitolszczyzna. Its population is convinced, that the church and monastery in the village were built on the order of Mary and according to her architectural project. The middleman between the Mother of God and the builders was supposed to be local clairvoyant Menka, called in a supernatural way to serve God.

KeYwords: Folk Christianity; unofficial believes; the Mother of God; Nowaci, Bitolszczyzna; Macedonia

Macedonię można nazwać ziemią biblijną od samego początku chrześcijaństwa, ponieważ pierwsi apostołowie i siewcy Chrystusowego Słowa kroczyli po naszych drogach. Istnieje prawdopodobieństwo, że na macedońskich ziemiach przebywała także Prześwięta Bogurodzica. Dotarła tu podczas swoich wędrówek ze św. Janem Ewangelistą ${ }^{1}$. Według ludowych

${ }^{1}$ Motyw wiązany z apokryficznymi opowieściami o dziejach św. Łazarza, Zaśnięciu Matki Bożej i z atoskim kultem pasa Bogurodzicy. Matka Boża miała płynąć ze św. Janem w odwiedziny do Łazarza na Cypr, jednak podczas sztormu statek się rozbił i zmuszeni zostali do zejścia na ląd u podnóża Athosu. W Słowiańszczyźnie motyw utrwalił św. Dymitr Rostowski (Daniel Tuptało, 1651-1709), wpisując go do historii Zaśnięcia Matki Bożej 
przekazów, pieśni, legend hagiograficznych Matka Boża zakładała najstarsze macedońskie cerkwie i brała je pod swoją opiekę, tak jak wzięła w wieczystą opiekę Świętą Górę Athos - „ogród Bogurodzicy” (cf. np. Naumow 2009: 21-30 i podana tam literatura). Do najstarszych macedońskich świątyń silnie związanych z tradycją maryjną należy między innymi cerkiew Bogurodzicy Slimnickiej w Prespie (Стојчевска-Антиќ, Николовски-Катин 2008: 36 і n.).

Od czasu oficjalnego przyjęcia chrześcijaństwa w IX wieku w Macedonii szczególnie intensywnie zaczęła rozwijać się architektura cerkiewna i monasterska. Jej matecznikiem były budowle wzniesione przez św. św. Klimenta i Nauma Ochrydzkich, którzy założyli Ochrydzką szkołę literacką. Późniejsze wieki przyniosły wielki rozkwit chrześcijańskiego budownictwa.

Również na Bitolszczyźnie rósł Kościół. Tak na przykład w XIII wieku arcybiskup Demetriusz Chomatianos ${ }^{2}$ odnotował istnienie monasteru pw. Dwunastu Apostołów w tym regionie. U schyłku XIV wieku na zboczu Płakeńskich Gór koło wsi Żwan zbudowano Toplicki monaster (Топлички манастир) pw. św. Mikołaja. W XVI wieku wzniesiono monaster we wsi Duowo, który został wspomniany w Zografskim dyptyku (Зографскиот поменик) z XVII wieku. Bogaty katalog starych macedońskich obiektów sakralnych sporządził Ilia Welew i opublikował w swojej książce Преглед на средновековни иркви и манастири во Македонија (Rejestr średniowiecznych macedońskich cerkwi i monasterów) (Велев 1990).

Przy cerkwiach i w monasterach troszczono się o rękopiśmienną spuściznę Macedończyków. W wielu świątyniach i ich bibliotekach odkryto drogocenne teksty, świadczy o tym obszerna literatura przedmiotu (np. Словенските ракописи во Македонија, 1971). Za przykład można podać monaster pw. Przemienienia Pańskiego, zbudowany na fundamentach dużo starszej świątyni koło wsi Bukowo (6 km od Bitoli), w którym

(15 sierpnia) i wydając drukiem w swoich Żywotach świętych (t. 4). Ruski hagiograf powołał się na świadectwo mnicha Stefana z Athosu.

${ }^{2}$ Urodzony w 1165 roku, zmarł w 1234 lub 1235 roku. Bizantyński teolog, hagiograf, arcybiskup Ochrydy (ok. 1216-1234), przeciwnik autokefalii Cerkwi serbskiej z 1219 roku (Misiurek 1989: 1145). 
odnaleziono rękopiśmienny Prolog ${ }^{3}$, pergaminowy Tetraewangeliarz ${ }^{4}$, Mineję $^{5}$ z XVI wieku, Oktoich ${ }^{6}$ drukowany w 1539 roku (Ќорнаков 2009) $\mathrm{i}$ in.

Życie chrześcijańskie zawsze było głęboko zakorzenione w macedońskim narodzie i troskliwie pielęgnowane aż do dziś. Od szeregu lat wespół z metropolitą Metodym Złatanowem badam obecność religii chrześcijańskiej w Macedonii. Rezultaty naszych studiów zostały ogłoszone w pięciu książkach cyklu По стапките на христијанството во Македонија (Po śladach chrześcijaństwa w Macedonii) - pierwsza publikacja wyszła w 2004 roku (Стојчевска-Антиќ, Златанов 2004), ostatnią książkę ukończyliśmy w 2013 roku.

Zauważalny rozwój budownictwa sakralnego w Macedonii nastąpił po upadku muru berlińskiego, gdy zlikwidowano stary ustrój polityczny. Wzrosła też liczba wiernych aktywnie uczestniczących w życiu religijnym i wspomagających kościelne budownictwo. Po raz pierwszy pojawili się poważni fundatorzy finansujący duże i bogate budynki świątynne, ale także znaczną liczbę mniejszych lub małych świątyń, na które datki przekazują również najbiedniejsi wierni.

Na Bitolszczyźnie życiem religijnym kieruje metropolita Piotr, który zainicjował budowę wielu nowych obiektów sakralnych. W samej Bitoli nadzoruje prace nad wielkim projektem architektonicznym rozpoczętym jeszcze w 1993 roku - ogromną cerkwią ${ }^{7}$ pw. Soboru ${ }^{8}$ Wszystkich

\footnotetext{
${ }^{3}$ Księga liturgiczna z krótkimi żywotami świętych (gr. synaksarion), wykorzystywanymi podczas nabożeństw.

${ }^{4}$ Zbiór obejmujący cztery Ewangelie Nowego Testamentu.

${ }^{5}$ Księga liturgiczna zawierająca materiał hymnograficzny (tzw. służby, oficja) ku czci świąt i świętych, ułożonych według porządku kalendarza i wykonywanych w dniu pamięci.

${ }^{6}$ Księga liturgiczna ośmiu tonów, zawierająca materiał hymnograficzny tygodniowego cyklu nabożeństw (wieczernie, powieczeria, jutrznie, liturgie sześciu zwykłych dni tygodnia; prócz tego małe wieczernie i nabożeństwa o północy niedziel). Pierwszy drukowany oktoich wydano w Krakowie w 1491 roku w drukarni Szwajpolta Fiola.

${ }^{7}$ Świątynia w założeniu ma być jedną z największych (lub nawet największą) w kraju i na całych Bałkanach.

${ }^{8}$ Święto kolektywne w kalendarzu Kościoła prawosławnego, gromadzi większą grupę świętych łączonych jakąś wspólną cechą (cechami). Tego typu zbiorowe dni pamięci upowszechniły się w okresie socjalizmu i często ustanawia się je obecnie - szczególnie w Kościele rosyjskim.
} 
Macedońskich Oświecicieli (Собор на сите македонски светители) ${ }^{9}$. $\mathrm{Na}$ kompleks świątynny składa się zespół oddzielnych cerkwi i kaplic poświęconych zarówno macedońskim, jak i powszechnym świętym. W najniższej części, pod apsydą ołtarzową, będzie się mieściła obszerna cerkiew Św. Pawła z dużą chrzcielnicą i sześcioma salami - czterema większymi i dwiema małymi ${ }^{10}$.

Metropolita Metody i ja uważaliśmy, że publikacje książkowe, w których pokazaliśmy rozwój religii chrześcijańskiej w Macedonii, wystarczą. Tymczasem, gdy tylko kończyliśmy badania w jakiejś diecezji, po roku lub dwóch latach budowano tam nowe świątynie; naturalnie część z nich nie miała wielkich rozmiarów - najczęściej była to realizacja marzenia o własnej lokalnej świątyni jakiegoś mieszkańca danej okolicy. Dziś wiemy, że badania nad budownictwem sakralnym należy prowadzić regularnie, gdyż liczba świątyń nieustannie wzrasta.

Najprawdopodobniej spośród byłych socjalistycznych państw bloku wschodniego ludność Macedonii wyróżnia się największym zainteresowaniem budową nowych cerkwi. Wznoszone są one nawet przez bardzo bierne i ubogie środowiska, co dowodzi silnego przywiązania do chrześcijańskiego światopoglądu, którego nigdy nie udało się w społeczeństwie wykorzenić.

Prowadzone przeze mnie i przez kolegów folklorystów badania terenowe zilustruje historia cerkwi pw. Przeświętej Bogurodzicy we wsi

${ }^{9}$ Pamięć liturgiczna Soboru obchodzona jest w pierwszą niedzielę października. Należą do niego: św. Lidia (I w. p.n.e. - I w. n.e.), mnich męczennik Erazm Ochrydzki (III-IV w.), św. Achilles Prespański (III-IV w.), mniszka pustelnica Synkletyka (,matka pustyni”; IV w.), cesarz Justynian I Wielki (V-VI w.), Teofil Wyznawca (Strumicki; VIII w.), Metody i Cyryl Równi Apostołom (IX w.), bp Kliment Ochrydzki (IX-X w.), mnich Naum Ochrydzki Cudotwórca (IX-X w.), mnich pustelnik Gabriel Lesnowski (XI w.), 15 męczenników Tyberiopolskich (Strumickich; IV w.), Joachim Osogowski (XI-XII w.), Grzegorz Ochrydzki (X-XI w.), arcybp Teofilakt Ochrydzki (XI-XII w.), mnich Hilarion (Iłarion) Megleński (XII w.), Jan Kukuzeł Anielskogłosy (XIII-XIV w.), mnich pustelnik Dionizy Kosturski (XIV w.), Nikodem Przylepsko-Tysmański (XIV w.), mnich Nektariusz Bitolski (XV w.), mnich pustelnik Prochor Pszyński (XI w.), męczennik Jerzy Kratowski (XV-XV w.), męczennik Jakub Kosturski i jego uczniowie - diakon Jakub i mnich Dionizy (XV-XVI w.), mnich Teofil Toczący Mirrę (XVI w.), męczennik Agatangel Bitolski (XVII-XVIII w.), męczennik Anastazy (Spas) Radowicki (XVIII w.), męczennica Złata (Chrysa) Megleńska (XVII w.), Nikita Serski (XVIII-XIX w.), Akakiusz Serski (XVIII-XIX w.), męczennik Nikodem Ochrydzki (XVIII-XIX w.).

${ }^{10}$ Zapisano w Bitoli 24 marca 2008 roku, w bitolskiej metropolii. 
Nowaci na Bitolszczyźnie. To nowa świątynia. Warto poznać historię jej budowy, jak również wierzenia chrześcijańskie z nią związane, ponieważ nie zawsze są one zgodne z surowymi kościelnymi kanonami. Mieliśmy możliwość poznać ją szczegółowo od Werki Kotewskiej, mieszkanki wsi urodzonej 20 lutego 1955 roku. Werka jest córką nieżyjącej już Menki Solunczewskiej, urodzonej 10 kwietnia 1928 roku w Demir Hisarze, a zmarłej 15 grudnia 2002 roku w Nowaci, słynnej we wsi z powodu swoich zdolności przewidywania przyszłości na podstawie snów. Werka opowiedziała nam takie zdarzenie:

Pierwszego maja (około 1986-1987) stała się rzecz następująca. Pewien rybak jadacy łowić ryby nad sztuczne jezioro koło Elektrociepłowni Bitola (РЕК „Битола”) miał wypadek gdzieś przed naszym domem samochodem Renault. Wraz z mężem obudziliśmy się o piątej rano, zbudził nas głośny huk trzykrotnie przewracającego się samochodu. Rybak byt caty, samochód tez nie byt uszkodzony. Widzieliśmy to osobiście. Przyjechała milicja, postawili samochód na koła i rybak spokojnie odjechat.

Koło Czarnej Rzeki zatrzymat się i zarzucit wędkę. Kiedy wyciagną haczyk, zamiast ryby wyłowit ikonę. Zdziwit się i z ikona wrócit prosto do swojej matki do Bitoli. Matka poradziła mu, by ikonę z obliczem Świętej Bogurodzicy trzymat w domu. Po kilku dniach rybak miat sen. Jakiś głos nakazat mu zwrócić ikonę na miejsce, na którym ją znalazt i tam zrobić jej kapliczkę. Rybak nie byt dobrze sytuowany, więc zamiast zrobić kapliczkę, postawit ikonę między cegłami. Po jakimś czasie dowiedziat się, że ktoś ukradt ikonę.

Po dwóch lub trzech latach od tego zdarzenia mojej mamie Mence, która nie miata żadnego kontaktu z rybakiem, przyśnit się sen. Objawiła jej się Bogurodzica i powiedziała, by poszła na parcelę, na której znaleziono ikonę. Opisała dokładnie tę parcelę. Menka na drugi dzień poszła na opisane miejsce, na którym była żęta pszenica. Tam mama znalazła kartkę papieru z obliczem Bogurodzicy. We śnie jej zasugerowano, żeby znaleziony obrazek oprawiła i chodziła z nim do ludzi. W ogóle, mama miała ciężkie życie. Kiedy mój ojciec byt $w$ wojsku, śniło jej się, że gorze $w$ mękach, a jej objawit się Jezus Chrystus i powiedziat, że musi zostać jego stugą. Ona była wtedy mężatka i myślała, że wiadomość trzeba było odebrać wcześniej. Za drugim razem poczuła silny ogień w sobie, naprawdę ptonęta i uciekta ze wsi, i upadta na skraju wsi. Płonęła, a kto przechodzit, rzucat na nia ziemię, by ja uratować od ognia i krzyku. Przyjechała też karetka pogotowia, i leżała trzy miesiace w szpitalu w Skopju. Ale potem urodziła trójke dzieci i żyła jak normalna kobieta. 
Gdy miała pięćdziesiąt sześć lat znów przyśnit jej się sen, że musi budować monaster na wcześniej wskazanym miejscu. Miejscem tym byt Kombinat Rolniczy „Pelagonia” (ЗИК „Пелагонија”) i ona w żaden sposób nie mogła uzyskać zgody, ale na koniec ja dostała. Zaczęła budować cerkiew w 1990 roku. Poświęcono krzyż $i$ wtedy powtórnie we śnie jej powiedziano, by opowiedziata o wszystkim publicznie. Bona Jankulowska wygłosiła wykład, a jedna uczennica recytowała wiersze. Przed mikrofonem pojawiła się też Menka i opowiedziała o snach, zaleceniach, budowie. Obecni płakali.

Dobrowolne datki na cerkiew dawaty instytucje ze wsi Nowaci, z Bitoli, zza oceanu, także emigranci. Plan cerkwi, wedlug wskazówek ze snów, moja matka objaśniała dwóm architektom: Mile Pecakowskiemu i Biljanie Nedelkowskiej. Menka mówiła im o najdrobniejszych detalach.

Interesujace, że ukradziona ikona, co ja zwrócit rybak Tome na miejsce, w którym była znaleziona, zaginęła i do dziś się nie odnalazła. Menka miała sen, że Bogurodzica poleciła, by zbudować schowek na ikonę z sześciu worków cementu, ale wtedy ikona została już ukradziona. Bogurodzica jej powiedziała, że tam jest już majster, który przyszedt budować, i naprawdę, kiedy Menka poszła na to miejsce, majster tam byt, to byt majster Stojancze z Nowaci. Menka dowiedziała się od niego, że i on miat ten sam sen i Bogurodzica mu powiedziata, by zbudowat schowek na ikonę. Ale oboje nie mieli pieniędzy. Kiedy Menka wróciła do domu, spotkała dwie młode kobiety i jednego mężczyznę, którzy przynieśli pieniądze na sześć worków cementu. Ludzie ci nie znali Menki, pracowali w Niemczech. Tego dnia musieli wracać do Niemiec i przyśnito im się, że musza zanieść pieniądze do Menki do Nowaci. Z tych pieniędzy Menka zbudowała mata cerkiewkę, naprzeciwko monasteru, koło rzeki. Ludzie, którzy przynieśli pieniądze, byli z Bitoli i wcześniej nie znali Menki. Gdy mała cerkiewka została zbudowana, Menka dostata nowe polecenie od Bogurodzicy, by zaniosta do niej suknię zrobiona w męce. Menka powiedziała jej, że nie ma takiej sukni, ale ma nowy kostium. Bogurodica wtedy się objawiła sąsiadce, i powiedziała, żeby zaniosła do Menki haftowany strój ludowy i ona powiedziała Mence: „We śnie przyszła do mnie Bogurodzica i mi powiedziała, żebym ci przyniosta ten cały takum [tu: wiejski strój kobiecy - V.S.-A.]". Menka zaniosła takum do cerkiewki. Bogurodzica jej powiedziała, że chce, by sama włożyła strój. Pewnej nocy strażnicy z elektrociepłowni widzieli silne światto i kobietę ubrana $w$ takum. Myśleli, że to Menka, wylegli zewszad i ruszyli do światta. Kiedy przybliżali się do światta, ono ginęto, a kiedy przyszli na miejsce - nie było nikogo. Po tym zdarzeniu Mence objawita się Bogurodzica: ,, Weź takum, ludzie będa tędy przechodzić, zabiora go, a on powinien być przechowywany w klasztorze, szczególnie podczas święta Małej Bogurodzicy, położony obok krzyża!”. 
Rybak Tome zmart, gdy miat 45 lat, dziesięć lat po znalezieniu ikony.

W monasterze i jego okolicach opowiadaja cuda. Bogurodzica objawia się we śnie wielu mieszkańcom. Tak na przykład opowiadała pewna Macedonka, która mieszkała w Australii, że we śnie Bogurodzica jej poradziła, by przyniosła stół do klasztoru. Ona przyniosła współczesny marmurowy stół na dziedziniec monasteru. Jej też się przyśniło, że powinna pójść do Menki do Nowaci i tak postapiła.

Menka zorganizowała też Komitet Cerkiewny, który się troszczy o donacje. Monaster jest w końcowej fazie, trzeba zrobić freski. Specjaliści pochodza ze Strugi i pracuja porządnie. Do Menki przychodzili ludzie z różnych stron, najczęściej po objawieniach we śnie. Ona wydawała cała pensję na monaster, na ludzi. We śnie miała przykazane, by parzyła wiernym kawę. Najczęściej komunikowała się z rybakiem Toma.

We wsi znany jest i taki cud: Menka leżała $w$ szpitalu, a powinna być 1 maja nad Święta wodą. Domownicy zabrali ją ze szpitala $i$ wcześnie rano zanieśli nad wodę. Byt tam tlum ludzi. Jakiś człowiek zaprowadzit Menkę do Świętej wody, w którą 1 maja patrzyła tylko Menka. Woda pojawiała się tylko 1 maja. Młody człowiek był ze Skopja. $W$ tym dniu Menka zabijała jagnię i o 12.00 przynosiła je na miejsce koło monasteru. Tego dnia nie byto jednak jagnięcia i zabito kokoszkę. Przy tym kura znalazła się w wodzie, która zaniosła ją daleko. Po 20 minutach kura wróciła do Menki. Później Menke odwieziono do szpitala, a domownicy ugotowali jej kurę i każdy, kto chciat, mógł próbować, bez zaproszenia. Ta woda jest cudowna i ludzie przychodza do niej modlić się.

Przewodniczacym Komitetu Cerkiewnego jest Weljo Tantarow. Opowiadat o problemach, które się pojawiaty zanim zaczęto budowę, a już w latach 1994-1995 oficjalnie otrzymano miejsce. Najwięcej datków przyszło z Kompanii Energetycznej ESM, z Kombinatu „Pelagonia”, kopalni Buczim koło Radowisz, Kompanii Tytoniowej „Makedonija-tabak” (od Szuturkowa ${ }^{11}$ ), z Elektrociepłowni Bitola i in. Komitet troszczy się o święto Matej Bogurodzicy. Minionego roku obiad sponsorowała Mleczarnia w Bitoli, a tego roku ${ }^{12}$ Kombinat ,Pelagonia”.

Wedtug ludowej tradycji, niegdyś znajdowat się tu monaster o tym samym wezwaniu. Podczas kopania odkryto czysty piasek. Tak samo jeden z robotników z koparka, Bagaczewski, opowiadat, że ostatnia tyżka koparki napetniła się srebrnymi pieniędzmi. Zakopat je powtórnie w fundamentach klasztoru. Dużo później opowiedział to zdarzenie Weljo Tantarowowi.

${ }^{11}$ Danczo Szuturkow (1935-2001) członek dyrekcji kombinatu.

${ }^{12}$ Określenia czasu nie są aktualne, informacje zbierane były w różnych okresach, te prawdopodobnie u schyłku lat 90 . XX w. 
Obchody dnia pamięci rozpoczynaja się 20 września, ale główna część święta odbywa się dzień później - 21 września. Uważa się, że monaster jest patronem rolników. Komitet planuje także budowę bazy noclegowej dla pielgrzymów. Sam monaster leży $w$ niezwykle urokliwej okolicy, otoczony wspaniała zieleniq. Ludzie bardzo o niego dbaja, utrzymuja w czystości $i^{13}$.

Z języka macedońskiego przełożyła Marzanna Kuczyńska

\section{Literatura}

Misiurek J., 1989, Demetriusz Chomatianos, w: Encyklopedia katolicka, t. 3, Lublin, s. 1145.

Naumow A., 2009, Pani Athosu i Jej ruskie włości, w: Święta Góra Athos w kulturze Europy. Europa w kulturze Athosu, red. M. Kuczyńska, Gniezno.

Велев И., 1990, Преглед на средновековни иркви и манастири во Македонија, Скопје.

Ќорнаков Д., 2009, Македонски манастири, Скопје.

Словенските ракописи во Македонија, 1971, подг. В. Мошин во соработка со Л. Славева, С. Кроневска и Ј. Јакимова, кн. І-ІІ, Скопје.

Стојчевска-Антиќ В., Златанов М., 2004, По стапките на христијанството во Македонија, 1, Скопје.

Стојчевска-Антиќ В., Николовски-Катин С., 2008, Ореолот на Дева Марија и Св. Богородица Слимничка во Преспа, Скопје, <http://www.slavekatin.com/knigi/ oreol/index.html>, 17.01.2016.

${ }^{13}$ Zapisano 25 marca 2007 roku, Wieś Nowaci, Bitolszczyzna. 